\title{
ERRATUM
}

\section{Chapter 20 \\ The Past Three Population Censuses: A Deepening Ageing Population in Indonesia}

\author{
Evi Nurvidya Arifin and Aris Ananta
}

(c) Springer International Publishing Switzerland 2016

C.Z. Guilmoto, G.W. Jones (eds.), Contemporary Demographic

Transformations in China, India and Indonesia, Demographic Transformation

and Socio-Economic Development 5, DOI 10.1007/978-3-319-24783-0

DOI 10.1007/978-3-319-24783-0_23

The affiliations of the authors of Chapter 20, Evi Nurvidya Arifin and Aris Ananta, were incorrectly published in the List of Contributors on Page ix and in the footnote present in the chapter opening page on page 309. The correct information is given below:

Evi Nurvidya Arifin

Centre for Ageing Studies, University of Indonesia, Depok, West Java, Indonesia

Aris Ananta

Faculty of Economics and Business, University of Indonesia, Depok, West Java, Indonesia 